\title{
The interplay between financial rules, trust and power in strategic partnerships in the construction industry
}

Financial rules, trust and power

\author{
Jelle Koolwijk, Clarine van Oel and Mirjam Bel \\ Faculty of Architecture and the Built Environment, \\ Department of Management in the Built Environment, \\ Delft University of Technology, Delft, The Netherlands
}

\begin{abstract}
Purpose - To explore how and why the social structures of strategic partnerships are shaped by actors and how these interrelate with a team's interpersonal relationships over time. Grasping the complexity of this interplay is essential if we want to comprehend what actually goes on in these partnerships and understand why actors often disengage from them.

Design/methodology/approach - In three cases, 14 in-depth interviews were held with knowledgeable actors about important events and activities that influenced the relationships between partners. Interview data were triangulated with journals kept by the lead author, who participated as an engaged scholar in the three cases. Because this study took an interdisciplinary approach, new insights could evolve from the multi-level analysis.

Findings - Trust has a moderating effect on the relation between open-book accounting and the degree of control a dominant party wants to exercise. When the level of control is raised, this can signal distrust to the other partners, which can harm the relationship. When partners feel more dependent on each other's capabilities to reach their long-term goals, the parties seem to be less likely to put the blame on one of the partners in the case of undesirable events.

Practical implications - Managers should be aware of their power position and acknowledge the effects of power on their relationships. If long-term and close collaboration does not emerge in their partnership, it may be due to how they use their power position.

Originality/value - Thanks to the interdisciplinary approach, this is the first study that shows the significance of trust and power in maintaining strategic partnerships in the construction industry, and how trust can affect the financial rules of actors.
\end{abstract}

Keywords Strategic partnering, Structuration theory, Power relations, Trust, Construction industry Paper type Research paper

C Jelle Koolwijk, Clarine van Oel and Mirjam Bel. Published by Emerald Publishing Limited. This article is published under the Creative Commons Attribution (CC BY 4.0) licence. Anyone may reproduce, distribute, translate and create derivative works of this article (for both commercial and non-commercial purposes), subject to full attribution to the original publication and authors. The full terms of this licence may be seen at http://creativecommons.org/licences/by/4.0/legalcode.

The authors gratefully acknowledge the two anonymous reviewers, and deputy editor Professor Georffrey Cheng for their very insightful comments on earlier versions of this paper. The authors wish to thank Dirk Zuiderveld for providing the information and contacts for the three cases. We should also like to thank the students participating in the Qualitative Research course at Delft University of Technology for joining Clarine van Oel during the interviews and for their help in transcribing them.

Data availability statement: The data used in this study cannot be made public due to restrictions imposed by the Human Research Ethics Committee at [university name] to prevent the release of information that could compromise the privacy of the research participants.

Declaration of interest: The authors declare no potential conflicts of interest with respect to the research, authorship and/or publication of this article.

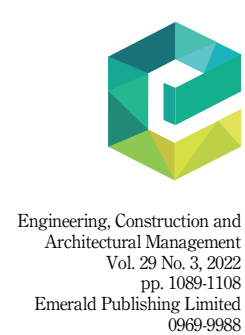

DOI 10.1108/ECAM-09-2020-0713 
ECAM

29,3

1090

\section{Introduction}

In many industries, strategic partnerships have become an important way for firms to cope with the challenges of doing business today (Gomes et al., 2016). Challenges such as climate change necessitate firms to innovate, which typically requires them to collaborate with complementary firms, as it allows them to share and integrate their knowledge and production capacities (Buckley et al., 2009; Edmondson and Nembhard, 2009; Sambasivan et al., 2013).

In the construction industry, long-term and cross-project partnerships are also thought to have many positive effects, such as providing learning opportunities and allowing cost reductions (Cheng et al., 2004; Ingirige and Sexton, 2006). To foster the development of strategic partnerships in the construction industry, much research has been done to understand the critical structural and relational elements of such partnerships (e.g. Cheng et al., 2004; Eriksson, 2015; Walker and Lloyd-Walker, 2015). Despite its potential, the concept of strategic partnering has not developed as strongly in the construction industry as in other industries (Bygballe et al., 2010; Sundquist et al., 2018). Case studies report that team members struggle with the partnership's social system because it contradicts earlier experiences that are often gained in more traditionally procured projects (Venselaar et al., 2015; Bygballe and Swärd, 2019).

Social systems consist of multiple dimensions that are constituted by social structures and individual actions that produce, reproduce and change these structures (Giddens, 1984). Social structures consist of rules and resources that help actors to give meaning to what they are doing and enable them to acquire power within the social system (Reimann and Ketchen, 2017). Partnering is based on different rules and power relations than is the case in traditional procurement, which can cause individuals who are new to this social system to feel disembedded (Giddens, 2013; Hartmann and Bresnen, 2011). Whereas traditional procurement is based on short-term and arm's-length relatsluionships, the aim of strategic partnering is to utilise the capacities of different firms by fostering long-term and close collaboration between individuals and integrating processes between firms (Koolwijk et al., 2018). For close collaboration to emerge, it is important that individuals have trust in both the rules of the social system and the individuals who constitute this system (Kähkönen, 2014; Mathieu et al., 2008). Furthermore, the power relations between the partners must be balanced (Kähkönen, 2014). A dominant partner that uses its power to influence the social system might be regarded as unfair by its partners, causing harm to the relationship (Pulles et al., 2014).

There is only limited knowledge about how and why the social structures of strategic partnerships are shaped by actors and how these interrelate with a team's interpersonal relationships over time (Bygballe and Swärd, 2019; Bresnen et al., 2005; Giddens, 1984). Grasping the complexity of this interplay is essential if we want to comprehend what actually goes on in these partnerships and understand why actors often disengage from them. In this study, we aimed to understand the significance of trust and power relations in maintaining strategic partnerships. Specifically, we sought to understand when dynamics in trust legitimise dominant actors to change the financial rules in strategic partnerships. In turn, we wanted to explore the effects of these changes on the interaction between parties in the supply chain and eventually their commitment to the partnership.

This article is organised as follows. First, the conceptual framework with sensitising concepts is described together with the three research questions. Then the methodology is explained, together with a further detailing of the three cases and the inductive approach used to identify interrelations in the data. Next, in the findings, we elaborate on the dynamics between rules and actions and the role of trust in balancing power relations in the three cases. Finally, we present our main conclusions and a discussion. 


\section{Conceptual framework}

Giddens's structuration theory provides an ontological vision about how to understand the interrelation between individual actions and social structures, in the sense that individuals shape social structures, but at the same time these structures influence the choices individuals make (Giddens, 1984). Structuration theory provides a basis on which research can be grafted. This basis must be provided with more substantial theory in order to be able to sensitise what actors know about why they exhibit certain behaviours and how they understand the social world around them. In the following paragraphs, a conceptual framework with sensitising concepts is developed on the basis of structuration theory.

\subsection{Structuration theory}

Giddens (1984) distinguishes three dimensions of a social system that can constrain or enable actors in their action: signification, legitimation and domination. These dimensions are constituted by social structures and individual actions. In their daily practices and interactions, individuals form, reproduce and transform structures (Gherardi and Strati, 2012) (see Figure 1).

Structures in a strategic partnership consist of rules and resources (Giddens, 1984). Rules define the inter-organisational objectives, procedures, formal relations and performance criteria. Rules help actors to give meaning to what they are doing and to define and perform particular activities (Giddens, 1984). Rules should not be understood as static "norms" for action, but are interpreted and negotiated in situated interaction (Gherardi and Strati, 2012). Resources enable a partner to acquire and possess power. Power is the capability of a partner to initiate a process or to take a decision in the supply chain by being in a dominant position in the social structure (Reimann and Ketchen, 2017). The concept of control in structuration theory suggests that partners that are in a subordinate position can still influence the social system, such as decision-making or behaviour, because they have a reciprocal relationship with the dominant partner (Reimann and Ketchen, 2017).

Actors use modalities - namely interpretive schemes, facilities and norms - to connect their processes of interaction with these structures. Systems of signification enable actors to interact by the use of their interpretive schemes. An interpretive scheme operates as an

\section{Dimensions of a social system}

\section{Signification Domination Legitimation}

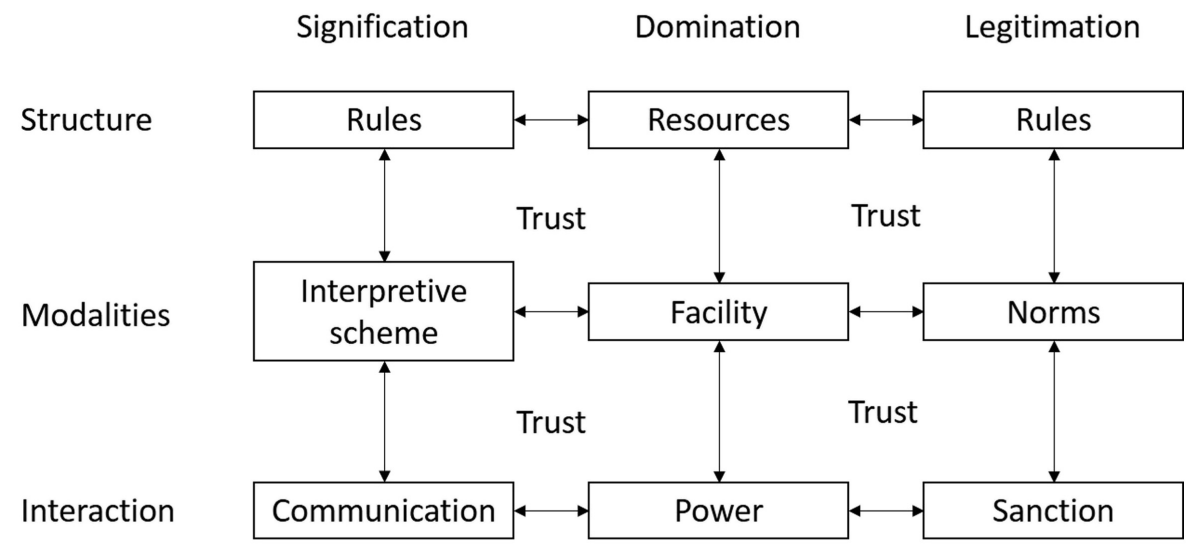

Source(s): Adapted from Giddens 1984, p. 29
Financial rules, trust and power
Figure 1. Structuration theory 
ECAM

29,3

1092

assumption about how and why people act in particular situations and makes it possible for an individual to identify an event in their life and to give meaning to this event (Bartunek, 1984). Systems of legitimation make it possible to sanction the interaction if an actor does not comply with norms (Falcone et al., 2013). Norms define how team members should interact, communicate and conduct themselves as members of the team. Systems of dominance facilitate actors to influence the course of action by the use of power. Actors use the three modalities simultaneously and interdependently when they produce, reproduce or transform social systems (Jones and Karsten, 2003). Trust is the "glue" that holds the social system together (Luhmann, 2000).

\subsection{Rules in strategic partnerships}

Strategic partnering (SP) is a delivery method in which the owner enters into a long-term, cross-project and multi-partner agreement with a contractor and key sub-contractors (Koolwijk et al., 2018). The term "strategy" is associated with the long-term objectives related to the organisation's long-term value and growth (Cheng et al., 2004). In the construction industry, this means that the contractor and other supplying partners are awarded a follow-up project when they deliver the project according to pre-specified project and partnership performance targets (Tennant and Fernie, 2014). The client's organisation benefits from the early involvement of key firms down the supply chain (Eriksson, 2015). Through early involvement in an integrated project team, these firms can contribute their organisation-specific knowledge to the design and increase their efficiency by integrating activities across firms, from which the clients benefits. Integration between firms includes inclusive decision-making, financial integration and information sharing (Koolwijk et al., 2018). Inclusive decision-making concerns the level of involvement of top and middle management in the project and joint decision-making by the client and suppliers (Koolwijk et al., 2018). Key partners need to be involved in decision-making and allowed to voice their concerns and opinions (Eriksson, 2015). Unless there is inclusive decision-making, sub-optimisation of the chain may occur (Arshinder et al., 2011). Information sharing is an important facilitator of an effective and efficient supply chain because it provides enhanced coordination between partners and opportunities for innovation within the joint team (Edmondson and Nembhard, 2009). This lowers the total costs of the supply chain, which is a major motivating factor in the formation of partnerships (Sambasivan et al., 2013).

Financial integration is realised through the sharing of risks and rewards and financial information (Koolwijk et al., 2018). Sharing risks and rewards should make partners look beyond the goals of their own organisation to the performance of the whole chain. Risks and rewards need to be shared across the partners on a fair basis (Narayanan and Raman, 2004). If incentives are not aligned, firms may revert to optimising their production (Rose and Manley, 2010). The sharing of financial risks and rewards by partners legitimises close collaboration and the sharing of information (Rose and Manley, 2010), because the partners will "sink or swim together" (Walker and Lloyd-Walker, 2015).

\subsection{Power relations in strategic partnerships}

In strategic partnerships in the construction industry, firms develop collaborative relationships to utilise the complementary capabilities and resources of their partners (Walker and Lloyd-Walker, 2015). Based on their capabilities, resources and position in the supply chain, firms have different power positions (Kähkönen, 2014). In the construction industry, a client has a dominant position in the supply chain because it is the sponsor of a project and is closest to the end-user (Kähkönen, 2014). Its contractor, however, has power because it has specific capabilities and resources that the client needs 
(Terpend and Krause, 2015). This power is often relative because there is a difference in dependence between the parties (Tennant and Fernie, 2014). When a client can easily replace a contractor, the client has a stronger position than in a situation where the client is more locked-in (Kähkönen, 2014).

Developing a collaborative long-term relationship requires a certain balance of power between the partners (Van Weele and Rozemeijer, 1996). This does not mean that both partners need to have a similar amount of power. It is the willingness of a partner to use its power position that determines the balance of power and in turn the collaboration between partners (Kähkönen, 2014). A powerful partner may use its power to change the rules, for instance the distribution of profit within the chain. If this action makes the weaker partner feel mistreated, it can decide to end the partnership (Pulles et al., 2014). However, a dominant partner whose long-term objectives are more dependent on the other partner might refrain from using its powers in order to maintain the long-term relationship (Reimann and Ketchen, 2017).

\subsection{Trust in strategic partnerships}

For close collaboration to emerge in a social system, it is important that individuals have trust in both the rules of the social system and the individuals who constitute this system (Giddens, 1991; Kähkönen, 2014). Without this trust, there is no rationale to continue the relationship (Luhmann, 2000), because it will negatively affect information sharing and close collaboration (Edmondson and Lei, 2014).

The decision to join a strategic partnership requires actors to place trust in the partnership's social system (Giddens, 1991). Especially inexperienced actors need to take a "leap of faith" to trust the rules, because they are rather unknowing about its inner workings (Hartmann and Bresnen, 2011; Jacobsson and Roth, 2014; Venselaar et al., 2015). Actors also need to place trust in each other. When the directors of two firms decide to integrate their activities in a strategic partnership, they know that they will become vulnerable to the actions of the other partner (Koolwijk, 2018; Leuschner et al., 2013). They are willing to accept the risks of integration, because they hold positive assumptions about the other partner. They perceive the other partner as someone who does not take advantage of them (Mcknight and Chervany, 2001), and who has the "ability, dependability, or competence to perform a task" (Pinto et al., 2009, p. 640). In other words, they decide to trust their partner based on past experiences or selection procedures that in some way are believed to be reliable indicators of the future (Glaister and Buckley, 1997).

The decision to place trust in both the partnership's social system and the actors within it does not mean that this trust will be sustained over time (Giddens, 1991). During their collaboration, each partner will learn about the true trustworthiness of the others (Kostis and Näsholm, 2018). By monitoring the behaviours of a partner regarding a particular situation, an actor can develop a notion of this partner's trustworthiness. Norms and trust are therefore closely linked (Falcone et al., 2013). Trust is reinforced by positive experiences and increased knowledge of the other and declines when expectations are not met (Lewicki et al., 2006). Trust within a project team is crucial to information sharing and close collaboration (Edmondson and Lei, 2014; Koolwijk et al., 2020). To develop and maintain this environment, norms are developed through team building activities, policies and contracts (Buvik and Rolfsen, 2015; Walker and Lloyd-Walker, 2015). When trust declines, however, the desire to control the behaviours of the partner is likely to increase in order to lower the exposure to risks posed by the relationship (Das and Teng, 1998). By increasing control, however, one could also signal distrust, which can lower the level of information sharing amongst team members and eventually their commitment to the partnership (Das and Teng, 1998, Mcknight and Chervany, 2001). 
ECAM

29,3

1094

\subsection{Interpretive schemes in strategic partnerships}

The interpretive schemes that people hold are formed by their backgrounds, experiences, values and interests (Putnam and Holmer, 1992). Therefore, any given event can be understood in multiple ways by different people (Giddens, 1984). Interpretive schemes can enable people to take action, as such schemes allow them to interpret ambiguous situations and reduce uncertainty in complex situations. However, interpretive schemes can also constrain people in their view of reality and inhibit reflexive thinking. When a team tries to understand a complex situation, the team members need to develop joint frames (Putnam and Holmer, 1992). These joint frames are developed through a process of interaction in which team members come to a joint understanding (Van Maanen and Schein, 1977). Because of their interpretive schemes, however, this process does not guarantee that the issue is well defined (Putnam and Holmer, 1992).

Case studies on strategic partnerships show that team members who are new to partnering often developed their perceptions about other partners in more traditionally procured projects (Venselaar et al., 2015; Bygballe and Swärd, 2019), which are characterised as low-trust relationships between firms (Hartmann and Bresnen, 2011). Team members need to discard these beliefs about their potential partners and develop new ones before they can trust and sustain the partnership's social system and the individuals who constitute this system (Jacobsson and Roth, 2014). Buvik and Rolfsen (2015) suggest that in the early stages of a project, this "leap of faith" can be taken through the early development of integrative work practices and norms within the project team. However, there is a possibility that this perception proves impervious to change (Mathieu et al., 2008). Hartmann and Bresnen (2011) report that deeply rooted values and beliefs are difficult to converge in the construction industry.

\subsection{The interplay between financial rules, trust and power relations}

Open-book accounting and financial incentive schemes are often used in the construction industry as tools for financial integration (Walker and Lloyd-Walker, 2016; Badenfelt, 2010). Under the condition of trust, open-book accounting can be considered an integrative activity that enables information sharing between partners (Fabbe-Costes and Jahre, 2008). Financial information is shared openly to facilitate discussion about design solutions and identify cost reductions (Cooper and Slagmulder, 1999). Under the condition of low trust, one might argue that open-book accounting is a control tool used as a safeguard against opportunism in the process of managing strategic partnerships (Vosselman and Meer-Kooistra, 2009). It is used to monitor the performance levels of each partner, comparing their individual contributions against standards and correcting or adjusting these as necessary (Vosselman and MeerKooistra, 2009). Cognitively, then, when the use of open-book accounting is changed by a dominant partner, this can signal that partners distrust one another (Badenfelt, 2010). Further, a dominant partner that uses its power to change the distribution of value in the chain can be perceived as unfair by the other partners and harm the relationship (Pulles et al., 2014). In contrast, when clients misperceive contractors as being opportunistic (Aminian, 2015), open-book accounting can also be used to counter those potential misperceptions and provide facts about the partners' actual performance (Cheung et al., 2013). Therefore, for the dominant partner trust plays a moderating role between open-book accounting and the level of control. In turn, the outcomes of control measures can affect the way partners perceive each other. This perception can be influenced by past experiences, especially in construction, where many actors learn to distrust each other in a traditional procurement environment (Hartmann and Bresnen, 2011). However, the issue of how and when partners decide to use their power positions in supply chain relationships has hardly been researched (Reimann and Ketchen, 2017). Trust might play an important role in balancing power relations 
(Kähkönen, 2014). Drawing upon the theoretical basis and research gap identified above, this Financial rules, study explored the following research questions:

(1) How does trust legitimise the use of power to change the financial rules in strategic partnerships?

(2) Under what conditions do partners refrain from using their power?

(3) How does the experience of individual agents affect the interplay between financial integration, power and trust in strategic partnerships?

The aim of answering these three questions was to deepen our understanding of why some strategic partnerships are maintained, whereas others are dissolved.

\section{Methodology}

\subsection{Rationale}

This exploratory research sought to develop a theory on the interplay between structure and individual actions grounded in data collected in strategic partnerships. To gain theoretical sensitivity, an initial conceptual framework was developed (Bowen, 2006; Charmaz, 2006). Data collection, data analysis and the development of the conceptual framework occurred concurrently (Bowen, 2006). Throughout the study, the initial theoretical background was supplemented with emergent concepts that provided clarity in thinking. To keep an open mind and counteract the possible negative effects of early engagement with literature on the research process, the trustworthiness standard was a key element of the research approach (Shenton, 2004). Because the stories that emerged from the data are complex and many-sided in nature, thick descriptions were made that allow this diversity (Flyvbjerg, 2006).

\subsection{Case study selection}

This study sampled cases that were homogeneous at the organisational and the contextual level in order to identify how internal structural characteristics might be related to informal processes in the partnership (Bennett, 2004). The comparison of multiple cases with similar structural properties made it possible to explore patterns of similarities and differences in how and when structural properties and informal processes interact.

A list of possible cases was created based on the knowledge held personally by the lead author and by the head of a management consulting firm both active in facilitating strategic partnerships in the Dutch construction industry. Additionally, data from a previous study by the lead author was used to identify strategic partnerships that met the selection criteria (Koolwijk, 2018). The cases selected met criteria for strategic partnering that had already been used by others in this field. They incorporated the main components of strategic partnerships in the construction industry and involved high levels of integration between the participating firms (Koolwijk, 2018; Ingirige and Sexton, 2006). Further details are provided below (Section 3.3).

\subsection{Case description}

3.3.1 Project and client characteristics. The three selected strategic partnerships were engaged in similar large-scale housing renovation projects in the Netherlands, initiated by a housing corporation. This gave a similar context to the partnerships. The projects were renovations of terraced houses and all involved similar works, such as roofing, installing new central heating systems and insulating outer walls. Tenants could also opt for new bathrooms, kitchens and toilets, with room for personal choices such as appliance selection. 
ECAM

29,3

1096

3.3.2 Scope and duration of the partnerships. Table 1 shows the scope of the organisations involved in each partnership. "Scope of integration" refers to the "nature and number of organisations or participants included in the integrated supply chain" (Fabbe-Costes and Jahre, 2008, p. 135). Partnership A consists of four partners, partnership B of five and partnership C of six. Furthermore, all three use "co-makers", namely parties that become involved when the construction phase is being planned, so as to align their activities with the main partners and other co-makers.

"Duration of integration" refers to the length of an established relationship in the form of projects previously delivered by the partnership (Eriksson, 2015). Participants in partnership A were interviewed when they were developing their third project. All the firms in partnership $\mathrm{C}$ had collaborated on two earlier projects and were working on their third when the first round of interviews was held; a second round was held during their fourth project. Finally, participants in partnership B were interviewed during the course of their first project. Three supplying firms in this partnership had previously participated in partnership A. For the client, this was the first project done on the basis of partnering.

3.3.3 Level of integration between partners. The head of the management consulting firm was involved in all three partnerships at the board level and organised them in the same way. Consequently, they were similar in terms of their formal organisational structure. We elaborate on this in more detail below.

With regard to the timing of involvement (Eriksson, 2015), partners become involved in a project during its definition phase. This is the point at which a partnership develops various design solutions and business cases showing the total cost of ownership for the client (here, the housing corporation). The client's board then decides which business case the partnership should develop further. Following that decision, the partnership continues to develop the design and project budget. Once the final plan fits within the business case and the project budget is approved by an external cost auditor, the works are awarded to the partnership by the client.

Organisationally, the partnership structure consists of three layers. At the top is the joint leadership team composed of board members from each partner. To prevent suboptimal performance along the chain of partners, each needs to be involved in decision-making (Arshinder et al., 2011; Eriksson, 2015). It takes the high-level decisions and allocates primary resources, such as project engineers and a project office, to the partnership. The middle layer is the senior management team, which leads the partnership on a day-to-day basis. This team is composed of project managers representing their own partner organisations. Project managers are important agents here, as they are responsible for tactical decisions and occupy a central position in communications between the boards of the partner organisations and the project team. They are the information brokers (Karrbom Gustavsson and Gohary, 2012; Müller et al., 2013) and they facilitate the sharing of financial information between the project team and the partner organisations (Walker and Lloyd-Walker, 2015) - a process that could affect the

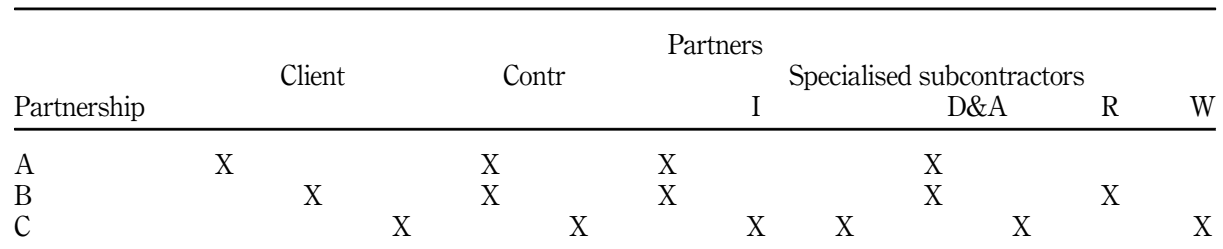

Table 1.

Scope of integration per case
Note(s): Abbreviations: Contr. = contractor; I = installations; D\&A = demolition and asbestos removal; $\mathrm{R}=$ roofing; $\mathrm{W}=$ window frames 
development of trust in the individual team members. They also have an important role in Financial rules, nurturing a no-blame atmosphere and teamwork throughout the project (Koolwijk et al., 2020). At the lowest level are the operational teams, composed of project engineers and quantity surveyors, who produce the design documents and realise the building. This operational layer is directed and informed by the senior management team (Müller et al., 2013).

Various integrative activities are undertaken jointly by the partners, such as risk identification and lean planning sessions. To stimulate close collaboration between the partners, a range of partnering practices are applied, such as a two-day teambuilding workshop at the start of each project and weekly team meetings to allow for ongoing communication (Buvik and Rolfsen, 2015; Lacerenza et al., 2018).

All three partnerships use the activity-based costing method to calculate their costs and share cost data; this is a technique in which the allocation of costs is based on the activities responsible for them. In the design phases, the partners are paid for their advice and design activities. On top of the costs it actually incurs, each partner receives a percentage of those costs as a profit margin. Once the design is finished and uncertainties are reduced, a guaranteed maximum price for the construction works is agreed. The project-related risks and cost savings are shared between the partners through a risk-reward fund, to provide an economic incentive for collaboration (Walker and Lloyd-Walker, 2015; Rose and Manley, 2010). This form of contract is not common in this branch of the construction industry, where fixed-price contracts with unit prices are still standard. The partnerships' performances were monitored on the basis of tenant participation in energy-efficiency measures, tenant satisfaction with the process and product, number of items per home on the punch list, cycle time per home and costs.

3.3.4 Outcomes of the four projects. In general, the four projects were seen as a success. They were delivered within the agreed budget and schedule, and production times per home were within the agreed limits. Each project received an A+ for tenant satisfaction. The level of participation in the energy-efficiency measures was above $95 \%$, which is regarded as very high. Each project experienced challenges as well, including unforeseen situations like hidden asbestos, but these were solved by the partners without great difficulties, major delays or excessive cost overruns.

\subsection{Case study protocol}

Between April 2016 and December 2017, interviews were conducted with key actors selected for their experience with the three strategic partnerships. We mainly focussed on members of the senior management team who represent client, contractor and subcontractor organisations, because of their central position within the partnership and to provide information from a variety of perspectives (Shenton, 2004). In some cases, we interviewed members from the joint leadership team to provide context to some of the stories that emerged from the data. In all, 14 interviews were held with key actors from different firms (see Table 2). All informants were interviewed in Dutch, their native language.

The in-depth interviews focused on important events and activities that, in the eyes of the key actors, could influence the relationships between partners. Probing questions were asked to encourage the interviewees to provide examples from practice and to elucidate their meaning (Moerman, 2010).

Because the lead author is affiliated with the firms involved in the cases, for the sake of impartiality the interviews were conducted by the second author. Each interview lasted 50-70 min and was audio recorded with the subject's permission. The interviews were transcribed verbatim for the purpose of analysis and to provide an audit trail. The transcripts were then checked for accuracy by the third author, who acted as research assistant, before being further analysed. 


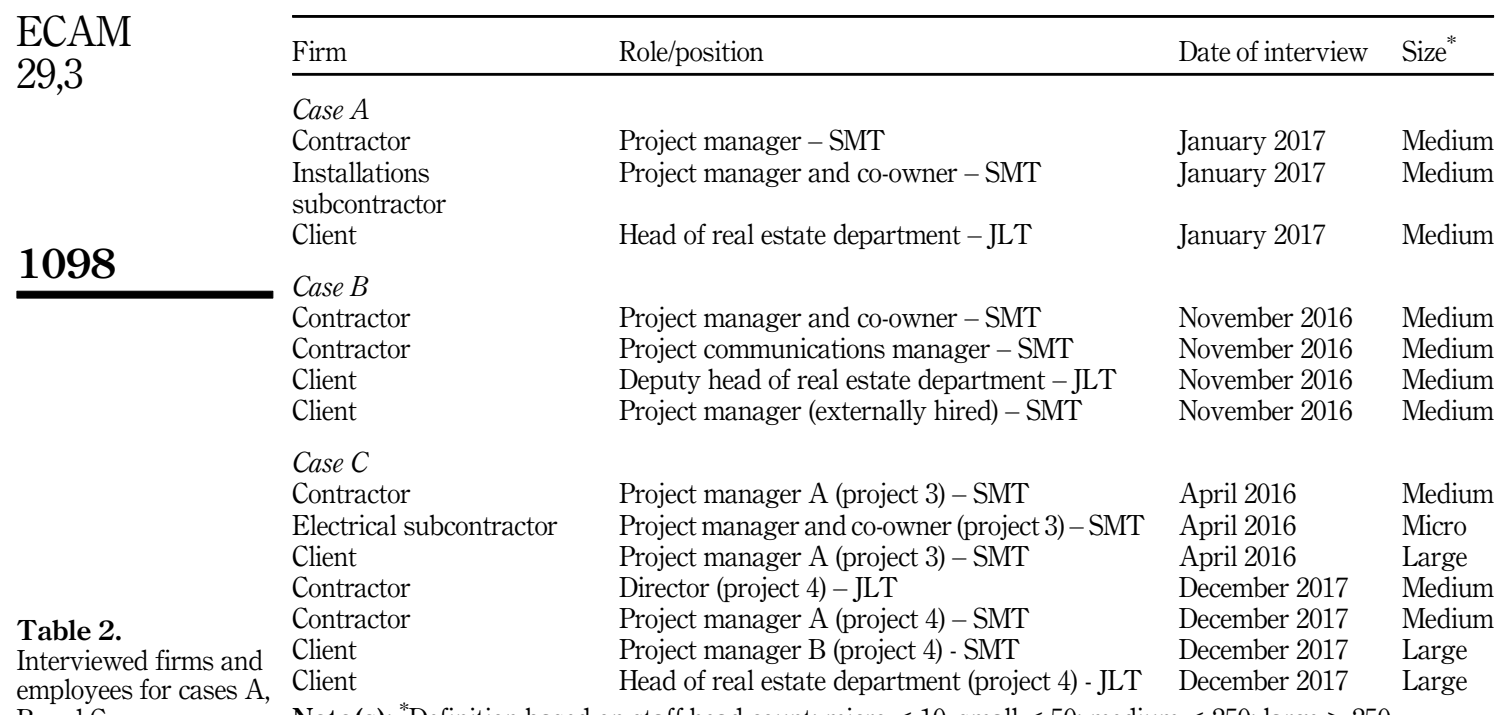

Note(s): "Definition based on staff head count: micro $<10$, small $<50$; medium $<250$; large $>250$

The thematic analysis began with the lead author and the research assistant reading and rereading the transcripts in search of patterns of meaning and issues of potential interest in the data (Braun and Clarke, 2006). Both then separately performed an initial coding using the sensitising concepts as interpretive devices (Bowen, 2006). Intimate involvement with the data led to the emergence of the theory. In this process, Atlas TI 7 was used as a tool. The research assistant is a novice researcher with little experience in studying the construction industry. The lead author is an experienced writer in the field of supply chain integration and collaboration and is active as a management consultant in the construction industry. Being an engaged scholar in the cases, he could add his own viewpoint and review his personal journals to help in understanding the complexity of each of them (Bäckstrand and Halldórsson, 2019). However, the interviews were used as the primary source to develop narratives to keep them close to how the individual actors experienced each situation. The constant comparison method was used to assess the coding categories that evolved from team meetings. The double-coding approach by two authors with different backgrounds ensured that neither forced their preconceptions upon the data (Kelle, 2007). This is important, as being an engaged scholar, tension could have emerged as a result of his company relations (Bäckstrand and Halldórsson, 2019). Finally, to establish the links between the salient features of the data, further content analysis was conducted using the different quotations under each code (Saldaña, 2015). The final thematic structures and story lines that emerged from the data were reported by the lead author and the research assistant in the form of thick descriptions, then discussed with the second author, who had performed the initial interviews. The second author is an expert in psychology. Because the lead and second author have different backgrounds, they had to cross boundaries, creating synergies and avoiding their disciplinary narrowness. Any differences in individual viewpoints about the main themes and plotlines were resolved through discussion and by closely rereading parts of the data until consensus was achieved. When the data did not uncover any new ideas about the theory, the coding stopped.

The interviews were held while the partnerships were still working on building projects. At the time they were conducted, it was unclear whether these partnerships would be 
continued after the projects were finished. Information about their continuation or termination was therefore obtained later, from the interviewees and from the head of the management consulting firm that had facilitated the three partnerships. After the four projects were completed, the authors conducted further short interviews with the client's project managers about their outcomes. In addition, they were shown the projects' periodic performance reports. Partnerships A and C were continued, whilst partnership B was put on hold for at least 18 months after the first project was delivered.

Financial rules, trust and power

\section{Findings}

\subsection{Case A: trust balancing power relations between contractor and subcontractor}

In case $\mathrm{A}$, a potential financial conflict developed between the contractor and an installation subcontractor who was running behind schedule and thus creating problems for the other firms in the production chain. The subcontractor's project manager explained:

When an installations subcontractor falls behind schedule, often the whole supply chain falls behind. (Installations subcontractor's project manager, case A)

To get back on track, the subcontractor's project manager tried to increase production speed by hiring more personnel.

However, "the supply of personnel was scarce at that time." He therefore "called 40 companies to ask whether they had hands available. In this specific case I found two plumbers. Or I thought they were plumbers, but they proved to be more like demolition workers... They caused me even more problems. . . So I put in a lot of effort to turn the situation around, but the project manager for the contractor thought I was messing up and that we were not in control." (Installations subcontractor's project manager, case A)

Initially, the subcontractor's project manager kept quiet about his difficulty in finding enough skilled personnel, which caused a considerable delay to the project. To get back on track, the other partners had to incur additional costs. Actual staffing levels were below those envisioned when the partners drew up a joint production schedule. The subcontractor's project manager explained that:

an open and honest talk, discussing how they should do things differently in the future. (Installations subcontractor's project manager, case A)

In the previous few years, the partners had developed a trusting and collaborative relationship, one that had created a unique value for both of them.

We have a history together. We won a [supply chain] prize together. That gives us a lot of togetherness. We think we're really good together. However, we also think we can always improve. . . We have a relationship. We've also done a lot of good projects. (Installations subcontractor's project manager, case A)

Because the collaboration is significant for both the contractor and the subcontractor and there is a basis of trust, they prefer to collaborate and commit to the partnership. The project manager of the contractor explained:

My director told me that we are a partnership together; this time it happened to the installations partner, the next time it will be us or the demolition partner. . That's strategic partnering: you know you'll do a project together next year, and another one a year after that. And so on. (Contractor's project manager, case A)

He underlined the importance of trust in building long-term collaborative relationships:

The basis of strategic alliancing is trust. If there is no trust, you can better stop. 
ECAM 29,3

Additionally, the contractor's project manager said that it is important to believe in the good intentions of your partner when there are issues, as that enables project team members

to put their knowledge on the table, because that is the strength of the partnership. (Contractor's project manager, case A)

\subsection{Case B: distrusting client uses its power to change the rules}

In case $B$, the deputy head of real estate at the housing corporation was inexperienced in strategic partnering. In the past, he had bad financial experiences with contractors in traditional projects and therefore started experimenting with other procurement approaches, such as design and build and partnering. The interviews took place immediately after an overt financial conflict at the time the first part of the renovation project was finalised. Neither the externally hired project manager nor the deputy head of real estate at the housing corporation entirely trusted the costs presented by the contractor and subcontractors. The deputy head explained:

In a strategic partnership, a contractor and subcontractors are involved early on and are paid for their activities. I felt that those costs were too high. The contractor was concealing profit by shifting things in the budget and thereby calculating the profit three times over. (Deputy head of real estate at housing corporation, case B)

He also stated that:

There is no trust between me and the contractor, [and] if you were to ask me if I would apply strategic partnering again, I would say no. (Deputy head of real estate at housing corporation, case B)

The externally hired project manager of the housing corporation had experienced a similar situation when working for another corporation in a strategic partnership.

The contractor and subcontractors were misusing the situation. They kept on booking hours, to the extent that it got out of proportion. (Project manager at housing corporation, case B)

Because they perceived the contractor as opportunistic, the deputy head of real estate and the project manager at the housing corporation felt legitimised to enhance the level of financial control. According to the contractor's project communications manager:

The deputy head at the corporation demanded more cost-specific information from the contractor's [project manager]. (Contractor's communication manager, case B)

The contractor's project manager explained the situation further, evidencing that when a dominant partner raises the level of control it can cause the subordinate partner to feel distrusted and unfairly treated (Pulles et al., 2014).

It is being suggested that we make a scandalous amount of money, while we can show them every offer and purchase invoice. We can refute everything ... First the client told us they wanted a [basic] list of materials. I showed them an example, which was agreed. However, eight weeks later they [the project manager of the client] wanted far more itemised documents. [Consequently, I am] working overtime, producing all these documents they require. At the same time the client tells me I'm booking too many hours... It's getting on my nerves [and] it also feels like everything is going in one direction. (Contractor's project manager, case B)

Because the deputy head of real estate and the externally hired project manager at the housing corporation did not trust the calculations presented by the contractor and the subcontractors, they raised the level of control further and hired an external cost consultant without informing the other partners. This shows how a dominant partner can use its position to change the rules of the social system. 
After an initial review of the project budget, the external cost consultant told the deputy Financial rules, head that:

The costs were not in line with current market prices. (Deputy head of real estate at housing corporation, case B)

power

However, at the time of the interview:

The cost consultant still needed to deliver the evidence. (Deputy head of real estate at housing corporation, case B)

Later, an expert on the activity-based costing method was asked to intervene after the contractor's project manager threatened to step out of the project. It turned out that the externally hired project manager at the housing corporation had not informed the external cost consultant that the partnership was using activity-based costing methods, and that the contractor and the subcontractors also provided design and other services to the partnership. This led him to make the false allegation against the contractor of hiding profit in the additional costs.

Increasing the level of financial control, however, undermined the level of trust between the partners. Six months later, the situation in case B brought the contractor's project manager to the point where he resigned from the project. The whole situation was exceptional for the supplying partners, to the extent that it made them reconsider their involvement in the project even though the tenants were highly satisfied with its outcomes.

\subsection{Case C: the effect of carrying frames from a traditional social system}

In case $\mathrm{C}$, no clear conflict in respect of costing was reported. However, the case resonates what has been mentioned concerning case B. The head of the real estate department explained how they framed contractors in the past and how much effort it takes to change these preconceptions. She also underlined the importance of trust in building long-term relationships.

We came from an era in which we procured our projects in a traditional way based on the lowest price. We saw contractors as parties that only wanted to make money from us. The word trust was not part of our dictionary at that time. Therefore, we could not trust each other in advance. When we started with strategic partnering, we did not speak about long-term agreements. It started with a project in which we needed to manage particular risks. We could only manage these risks together with the contractor. So, I started to ask my board members if we could select a contractor in a different way. There was a lot of resistance, but after a while they gave me permission to go ahead, but cautiously. We started with a first pilot project, then a second and a third pilot project [with different contractors]. We started with contractor $\mathrm{X}$, but why not $\mathrm{Y}$ and $\mathrm{Z}$ ? So we also tried it with those contractors. And then one of these pilot projects slowly developed into something that looked like a trustworthy relationship, something that could last longer. It was actually in this project that, for the first time, we really started to talk about the long term. (Head of the real estate department at housing corporation, case C)

Furthermore, the contractor's project manager mentioned the difficulties that arose when a new project manager at the housing corporation had a background in traditional procurement. In two subsequent projects in case $\mathrm{C}$, the new project manager at the housing corporation clearly lacked partnering experience. As the other five supplying partner firms kept the same project managers on the team, and thus had developed partnering routines earlier, they went too fast for the newcomer.

I had to work with a new project manager, who was inexperienced in strategic partnering and came directly from "traditional procurement land", so did not have a clue what was going on. (Contractor's project manager, case $\mathrm{C}$ ) 
ECAM

29,3

1102

This resulted in numerous heated discussions between him and the representatives of the other partners about, for instance, costing. Project manager A at the housing corporation talked about the "leap of faith" people need to take when they start working in strategic partnerships:

You need to see the advantages. If you have doubts about it, it is not going to work. I've got colleagues who think "This is not going to work". When they think like that, it's of no use. (Project manager $\mathrm{A}$ at housing corporation, case $\mathrm{C}$ ).

And about how trust and financial integration are related:

Trust is the basis: we should be able to assume that the costs presented by our partners are the actual costs. (Project manager A at housing corporation, case C)

The housing corporation acknowledged the difficulties caused by repeatedly changing its project manager, as the one assigned to the final project admitted:

It would be better if there were not as many changes. . Changing the team for every project is not very effective. (Project manager B at housing corporation, case C)

Echoing this, the head of the real estate department said that:

It takes time for them to learn and understand their new role. (Head of the real estate department at housing corporation, case $\mathrm{C}$ )

The housing corporation changed its project managers on purpose, however, in order to make itself less vulnerable to staff turnover by familiarising more project managers with this kind of role.

The following table presents the similarities and differences across the three cases to support the theoretical predictions (see Table 3).

\section{Conclusions and discussion}

The aim of this research was to investigate the interplay between rules, trust and power relations in strategic partnerships in the Dutch construction industry and to answer three questions: (1) How does trust legitimise the use of power to change the rules in strategic partnerships? (2) Under what conditions do partners refrain from using their power? (3) How does the experience of individual agents affect the interplay between rules, power and trust in strategic partnerships?

It can be concluded that trust has a moderating effect between open-book accounting and the degree of control a dominant party wants to exercise. The dominant party, in particular, is in a position to adjust the rules regarding the use of open-book accounting. In case B, the dominant party used its position to increase its control. Initially, the dominant party

Table 3.

\begin{tabular}{|c|c|c|c|c|c|c|c|}
\hline Case & Dominant & Subordinate & $\begin{array}{l}\text { Experience in } \\
\text { partnering }\end{array}$ & Trust & $\begin{array}{l}\text { Power } \\
\text { use }\end{array}$ & $\begin{array}{l}\text { (Expected) } \\
\text { rule change }\end{array}$ & Outcome \\
\hline $\mathrm{A}$ & Contractor & Subcontractor & $\begin{array}{l}\text { Contractor PM } \\
\text { Subcontractor PM }\end{array}$ & Yes & No & $\begin{array}{l}\text { Financial } \\
\text { integration }\end{array}$ & Engage \\
\hline B & Client & Contractor & Contractor PM & No & Yes & $\begin{array}{l}\text { Financial } \\
\text { integration }\end{array}$ & Disengage \\
\hline $\mathrm{C}$ & Client & Contractor & Contractor PM & Yes & No & $\begin{array}{l}\text { Financial } \\
\text { integration }\end{array}$ & Engage \\
\hline
\end{tabular}


demanded more information from the subordinate party. It then hired an external cost expert without involving the subordinate party. As a result, the subordinate party felt distrusted by the dominant party. Ultimately, this made the representative of the subordinate party disengage. In case A, we see that the parties had built up a relationship of trust over the years. This kept the dominant party from redistributing the financial value of the project and instead focus on what is needed to avoid the same mistakes in future projects.

In cases $\mathrm{A}$ and $\mathrm{C}$, the parties indicated that the collaboration is of unique value to them. Because they feel dependent on each other's capabilities, they seem to be more committed to long-term cooperation and less likely to put the blame on one of the partners. The combination of the two factors makes the dominant party less inclined to increase control when problems arise. In case B, the construction client appeared to have taken a more dominant role and saw partnering as a way to obviate the type of financial problems that arise in more traditional projects. The lack of trust, however, prompted the dominant party to apply more control over the contractor. This decision ultimately had disastrous consequences for the collaboration.

The three cases seem to suggest that the experiences of the involved actors play an important role in the development of a financial conflict and a lack of confidence. In case B, both the head of the real estate department and the project manager were relatively inexperienced in partnering. In addition, both had bad experiences with contractors in the past. The results seem to suggest that these experiences had greatly influenced their view of contractors, despite the team building and other group activities the joint team had been through together. Case $\mathrm{C}$ appears to support this finding: the interviewees clearly indicated that a lack of partnering experience can lead to discussions about money and the way of working together. In contrast to case B, however, in case $\mathrm{C}$ the head of the real estate department expressed his trust in his department's partners. Actors must have confidence in the principle of partnering from the start, otherwise it is of no use to embark on it. In addition, trust must be confirmed in the collaboration. In case $\mathrm{C}$, a number of projects had to be carried out with a number of contractors before there was sufficient confidence in one of these contractors.

Previous studies in other industries indicated that long-term and close collaboration can arise only if there is a certain balance in power relationships between the parties involved (Van Weele and Rozemeijer, 1996). The present research shows that when the dominant party uses its power to adjust the rules in the social system, this can lead to the disruption of the relationship. This finding is therefore in line with previous research (Kähkönen, 2014; Pulles et al., 2014).

Trust is often cited as the "lubricant" of long-term relationships (Venselaar et al., 2015). The present research shows how the degree of trust can influence the degree of control that the dominant party wants to exercise over the subordinate party. This finding confirms Das and Teng's (1998) ideas about the role of trust in strategic partnerships and its effects on the use of control measures.

Bresnen (2009) suggested that partnering emerges through the interaction of actors who work for different organisations. The results of this study support these findings. In particular, people's perceptions seem to have a major influence on how partnering evolves. Perceptions can differ from person to person and thus influence the dynamics and ultimate form of partnering. This finding may explain why partnering is shaped in different ways in the construction industry (Nyström, 2008; Koolwijk et al., 2018).

Buvik and Rolfsen (2015) suggested that the creation of trust between parties can be accelerated by applying certain interventions at the start of a project. Although such interventions took place in all three cases, in one of the cases the interaction nevertheless led to a decline in confidence. Bringing moments of reflection into the process therefore seems very important to make people aware of their patterns (Hartmann and Bresnen, 2011). 
ECAM

29,3

1104

However, trust can sometimes prove difficult to restore (Mathieu et al., 2008), especially when a collective feeling of mistrust arises within the team of one of the parties.

This research offers a new perspective on the actual problems practitioners face in strategic partnerships. It shows that both structural and relational elements are involved in the activities of actors and highlights how trust can affect the financial rules of actors. Thanks to the interdisciplinary approach, these new insights could evolve from a multi-level analysis. In this sense, this study can act as a guide to new research into the field of interorganisational collaboration in the construction industry. In this industry, the dominant approach is that collaboration is mainly determined by legal boundaries (Koolwijk et al., 2018). Koolwijk et al. (2018), however, provided evidence that long-term and close collaboration can emerge irrespective of the project delivery method used. In this industry, therefore, a new theory on inter-organisational collaboration can develop when researchers give up their disciplinary narrowness. More interdisciplinary research will facilitate theoretical development, because forces researchers to cross boundaries between fields, such as social psychology and supply chain management. This is not an easy task, but a necessary one if we want to deepen our insight into the dynamics practitioners face in strategic partnerships.

\subsection{Limitations and suggestions for further research}

Although the findings presented here are based on three cases, there are limitations with regard to the generalisation of the results. More in-depth and interdisciplinary research is needed to further clarify the specific power relationships and their effect on the practices of different parties. In addition, more research is needed into the relative importance of trust in regard to the power relation. Especially in situations where one of the parties is highly dependent, it could be that trust is faked in order to maintain the relationship. More research is also needed into how people's frames affect their future interactions. Frames developed in the past can have a major influence on the way people interact with each other in the future and thus hinder new forms of collaboration.

\subsection{Practical implications}

The results of this study have implications for practitioners involved in strategic partnerships in the construction industry. A firms' capabilities, resources and position in the supply chain determine their power relations. Managers should be aware of their power position and acknowledge the effects of power on their relationships. If long-term and close collaboration does not emerge in their partnership, it may be due to how they use their power position.

Our findings show that the past experiences of actors can influence their future collaborations. Although the joint teams were trained in various ways in partnering practices, trust proved impervious to change in one of the cases. The slow and step-by-step development of a trusting relationship is therefore warranted if firms want to develop longterm partnerships in the construction industry.

\section{References}

Aminian, E. (2015), A Study of Inter-firm Opportunism in the Construction Industry, The University of Manchester, Manchester.

Arshinder, K., Kanda, A. and Deshmukh, S. (2011), "A review on supply chain coordination: coordination mechanisms, managing uncertainty and research directions”, in Choi, T.-M. and Cheng, T.C.E. (Eds), Supply Chain Coordination under Uncertainty, Springer, New York, NY. 
Bäckstrand, J. and Halldórsson, Á. (2019), "Engaged Scholar (ship) in purchasing and supply management (PSM): creative tension or squeezed in the middle?", Journal of Purchasing and Supply Management, Vol. 25, 100557.

Badenfelt, U. (2010), "I trust you, I trust you not: a longitudinal study of control mechanisms in incentive contracts", Construction Management and Economics, Vol. 28, pp. 301-310.

Bartunek, J.M. (1984), "Changing interpretive schemes and organizational restructuring: the example of a religious order", Administrative Science Quarterly, Vol. 29, pp. 355-372.

Bennett, A. (2004), "Case study methods: design, use, and comparative advantages", in Sprinz, D.F.

Financial rules, trust and power and Wolinsky, Y. (Eds), Model, Numbers and Cases: Methods for Studying International Relations, The University of Michigan Press, Ann Arbor.

Bowen, G.A. (2006), "Grounded theory and sensitizing concepts", International Journal of Qualitative Methods, Vol. 5, pp. 12-23.

Braun, V. and Clarke, V. (2006), "Using thematic analysis in psychology", Qualitative Research in Psychology, Vol. 3, pp. 77-101.

Bresnen, M. (2009), “Living the dream? Understanding partnering as emergent practice”, Construction Management and Economics, Vol. 27, pp. 923-933.

Bresnen, M., Goussevskaia, A. and Swan, J. (2005), "Implementing change in construction project organizations: exploring the interplay between structure and agency", Building Research and Information, Vol. 33, pp. 547-560.

Buckley, P.J., Glaister, K.W., Klijn, E. and Tan, H. (2009), "Knowledge accession and knowledge acquisition in strategic alliances: the impact of supplementary and complementary dimensions", British Journal of Management, Vol. 20, pp. 598-609.

Buvik, M.P. and Rolfsen, M. (2015), "Prior ties and trust development in project teams-a case study from the construction industry", International Journal of Project Management, Vol. 33, pp. 1484-1494.

Bygballe, L.E. and Swärd, A. (2019), "Collaborative project delivery models and the role of routines in institutionalizing partnering", Project Management Journal, Vol. 50, pp. 161-176.

Bygballe, L.E., Jahre, M. and Swärd, A. (2010), "Partnering relationships in construction: a literature review", Journal of Purchasing and Supply Management, Vol. 16, pp. 239-253.

Charmaz, K. (2006), Constructing Grounded Theory: A Practical Guide through Qualitative Analysis, Sage Publications, Thousand Oaks, CA.

Cheng, E.W., Li, H., Love, P.E. and Irani, Z. (2004), "Strategic alliances: a model for establishing longterm commitment to inter-organizational relations in construction", Building and Environment, Vol. 39, pp. 459-468.

Cheung, S.O., Yiu, T.W. and Lam, M.C. (2013), "Interweaving trust and communication with project performance", Journal of Construction Engineering and Management, Vol. 139, pp. 941-950.

Cooper, R. and Slagmulder, R. (1999), "Supply chain management for lean enterprises: interorganizational cost management", Strategic Finance, Vol. 80, pp. 15-17.

Das, T.K. and Teng, B.-S. (1998), "Between trust and control: developing confidence in partner cooperation in alliances", Academy of Management Review, Vol. 23, pp. 491-512.

Edmondson, A.C. and Lei, Z. (2014), "Psychological safety: the history, renaissance, and future of an interpersonal construct”, Annual Review of Organizational Psychology and Organizational Behaviour, Vol. 1, pp. 23-43.

Edmondson, A.C. and Nembhard, I.M. (2009), "Product development and learning in project teams: the challenges are the benefits", Journal of Product Innovation Management, Vol. 26, pp. 123-138.

Eriksson, P.E. (2015), "Partnering in engineering projects: four dimensions of supply chain integration", Journal of Purchasing and Supply Management, Vol. 21, pp. 38-50.

Fabbe-Costes, N. and Jahre, M. (2008), "Supply chain integration and performance: a review of the evidence", International Journal of Logistics Management, Vol. 19, pp. 130-154. 
ECAM

29,3

1106

Falcone, R., Castelfranchi, C., Cardoso, H.L., Jones, A. and Oliveira, E. (2013), "Norms and trust", in Ossowski, S. (Ed.), Agreement Technologies, Springer, Dordrecht.

Flyvbjerg, B. (2006), "Five misunderstandings about case-study research", Qualitative Inquiry, Vol. 12, pp. 219-245.

Gherardi, S. and Strati, A. (2012), Learning and Knowing in Practice-Based Studies, Edward Elgar Publishing, Cheltenham.

Giddens, A. (1984), The Constitution of Society: Outline of the Theory of Structuration, University of California Press, Oakland, CA.

Giddens, A. (1991), Modernity and Self-Identity: Self and Society in the Late Modern Age, Stanford university press, Palo Alto, CA.

Giddens, A. (2013), The Consequences of Modernity, John Wiley \& Sons, Hoboken, NJ.

Glaister, K.W. and Buckley, P.J. (1997), "Task-related and partner-related selection criteria in UK international joint ventures", British Journal of Management, Vol. 8, pp. 199-222.

Gomes, E., Barnes, B.R. and Mahmood, T. (2016), "A 22 year review of strategic alliance research in the leading management journals", International Business Review, Vol. 25, pp. 15-27.

Hartmann, A. and Bresnen, M. (2011), "The emergence of partnering in construction practice: an activity theory perspective”, Engineering Project Organization Journal, Vol. 1, pp. 41-52.

Ingirige, B. and Sexton, M. (2006), "Alliances in construction: investigating initiatives and barriers for long-term collaboration”, Engineering Construction and Architectural Management, Vol. 13, pp. 521-535.

Jacobsson, M. and Roth, P. (2014), "Towards a shift in mindset: partnering projects as engagement platforms", Construction Management and Economics, Vol. 32, pp. 419-432.

Jones, M. and Karsten, H. (2003), Review: Structuration Theory and Information Systems Research, Judge Institute of Management Working Paper, Judge Institute of Management.

Kähkönen, A.-K. (2014), “The influence of power position on the depth of collaboration”, Supply Chain Management: International Journal, Vol. 19, pp. 17-30, doi: 10.1108/SCM-03-2013-0079.

Karrbom Gustavsson, T. and Gohary, H. (2012), "Boundary action in construction projects: new collaborative project practices", International Journal of Managing Projects in Business, Vol. 5, pp. 364-376.

Kelle, U. (2007), “Emergence' vs. 'forcing' of empirical data? A crucial problem of 'grounded theory' reconsidered”, Historical Social Research / Historische Sozialforschung, Vol. 19, pp. 133-156.

Koolwijk, J.S.J., Oel, C.J.V., Wamelink, J.W.F. and Vrijhoef, R. (2018), "Collaboration and integration in project-based supply chains in the construction industry", Journal of Management in Engineering, Vol. 34, 04018001.

Koolwijk, J.S.J., Oel, C.J.V. and Moreno, J.C.G. (2020), "No blame culture and the effectiveness of projectbased design teams in the construction industry: the mediating role of teamwork", Journal of Management in Engineering, Vol. 36, 04020033.

Kostis, A. and Näsholm, M.H. (2018), "Balancing trust and distrust in strategic alliances", in Das, T.K. (Ed.), Managing Trust in Strategic Alliances, Information Age Publishing, Charlotte, NC.

Lacerenza, C.N., Marlow, S.L., Tannenbaum, S.I. and Salas, E. (2018), "Team development interventions: evidence-based approaches for improving teamwork", American Psychologist, Vol. 73, p. 517.

Leuschner, R., Rogers, D.S. and Charvet, F.F. (2013), "A meta-analysis of supply chain integration and firm performance", Journal of Supply Chain Management, Vol. 49, pp. 34-57.

Lewicki, R.J., Tomlinson, E.C. and Gillespie, N. (2006), "Models of interpersonal trust development: theoretical approaches, empirical evidence, and future directions", Journal of Management, Vol. 32, pp. 991-1022.

Luhmann, N. (2000), "Familiarity, confidence, trust: problems and alternatives", in Gambetta, D. (Ed.), Trust: Making and Breaking Cooperative Relations, University of Oxford, Oxford. 
Mathieu, J., Maynard, M.T., Rapp, T. and Gilson, L. (2008), “Team effectiveness 1997-2007: a review of recent advancements and a glimpse into the future", Journal of Management, Vol. 34, pp. 410-476.

Mcknight, D.H. and Chervany, N.L. (2001), "Trust and distrust definitions: one bite at a time", in Falcone, R., Singh, M. and Tan, Y.-H. (Eds), Trust in Cyber-Societies, Springer-Verlag, Berlin Heidelberg.

Moerman, G. (2010), Probing Behaviour in Open Interviews, A Field Experiment on the Effects of Probing Tactics on Quality of Content of the Received Information, $\mathrm{PhD}$, VU University, Amsterdam.

Müller, R., Glückler, J., Aubry, M. and Shao, J. (2013), "Project management knowledge flows in networks of project managers and project management offices: a case study in the pharmaceutical industry", Project Management Journal, Vol. 44, pp. 4-19.

Narayanan, V. and Raman, A. (2004), "Aligning incentives in supply chains", Harvard Business Review, Vol. 82, pp. 94-102.

Nyström, J. (2008), “A quasi-experimental evaluation of partnering”, Construction Management and Economics, Vol. 26, pp. 531-541.

Pinto, J.K., Slevin, D.P. and English, B. (2009), "Trust in projects: an empirical assessment of owner/ contractor relationships", International Journal of Project Management, Vol. 27, pp. 638-648.

Pulles, N.J., Veldman, J., Schiele, H. and Sierksma, H. (2014), "Pressure or pamper? The effects of power and trust dimensions on supplier resource allocation", Journal of Supply Chain Management, Vol. 50, pp. 16-36.

Putnam, L.L. and Holmer, M. (1992), "Framing, reframing, and issue development", Sage Annual Reviews of Communication Research, Vol. 20, pp. 128-155.

Reimann, F. and Ketchen, D.J. Jr (2017), "Power in supply chain management”, Journal of Supply Chain Management, Vol. 53, pp. 3-9.

Rose, T.M. and Manley, K. (2010), "Financial incentives and advanced construction procurement systems", Project Management Journal, Vol. 41, pp. 40-50.

Saldaña, J. (2015), The Coding Manual for Qualitative Researchers, Sage Publications, London.

Sambasivan, M., SIEW-Phaik, L., Mohamed, Z.A. and Leong, Y.C. (2013), "Factors influencing strategic alliance outcomes in a manufacturing supply chain: role of alliance motives, interdependence, asset specificity and relational capital", International Journal of Production Economics, Vol. 141, pp. 339-351.

Shenton, A.K. (2004), "Strategies for ensuring trustworthiness in qualitative research projects", Education for Information, Vol. 22, pp. 63-75.

Sundquist, V., Hulthén, K. and Gadde, L.E. (2018), "From project partnering towards strategic supplier partnering", Engineering Construction and Architectural Management, Vol. 25, pp. 358-373.

Tennant, S. and Fernie, S. (2014), "Theory to practice: a typology of supply chain management in construction”, International Journal of Construction Management, Vol. 14, pp. 56-66.

Terpend, R. and Krause, D.R. (2015), "Competition or cooperation? Promoting supplier performance with incentives under varying conditions of dependence", Journal of Supply Chain Management, Vol. 51, pp. 29-53.

Van Maanen, J.E. and Schein, E.H. (1977), "Toward a theory of organizational socialization”, in Staw, B. (Ed.), Annual Review of Research in Organizational Behaviour, JIP Press, New York, NY.

Van Weele, A.J. and Rozemeijer, F.A. (1996), "Revolution in purchasing: building competitive power through proactive", European Journal of Purchasing and Supply Management, Vol. 2, pp. 153-160.

Venselaar, M., Gruis, V. and Verhoeven, F. (2015), "Implementing supply chain partnering in the construction industry: work floor experiences within a Dutch housing association", Journal of Purchasing and Supply Management, Vol. 21, pp. 1-8. 
ECAM

29,3

1108
Vosselman, E. and Meer-Kooistra, J. (2009), "Accounting for control and trust building in interfirm transactional relationships”, Accounting, Organizations and Society, Vol. 34, pp. 267-283.

Walker, D.H.T. and Lloyd-Walker, B.M. (2015), Collaborative Project Procurement Arrangements, Newton Square, Project Management Institute, Pennsylvania.

Walker, D.H. and Lloyd-Walker, B.M. (2016), "Understanding the motivation and context for alliancing in the Australian construction industry”, International Journal of Managing Projects in Business, Vol. 9, pp. 74-93.

\section{Corresponding author}

Jelle Koolwijk can be contacted at: j.s.j.koolwijk@tudelft.nl

For instructions on how to order reprints of this article, please visit our website: www.emeraldgrouppublishing.com/licensing/reprints.htm Or contact us for further details: permissions@emeraldinsight.com 